\title{
Microbiological Quality of Some Puerto Rican Fast Foods. I. Processor Level; Frozen or Refrigerated ${ }^{1}$
}

\author{
F. Fernández-Coll ${ }^{2}$
}

\section{ABSTRACT}

\begin{abstract}
A microbiological study was carried out to determine the microbial quality, at the processor's level, of refrigerated and frozen "pastelillos" and "empanadillas" (turnovers) produced locally. Results indicated that the "empanadillas" generally possessed higher initial microbial counts than the "pasteliIlos" and also exhibited an average shorter refrigerated shelf life (28 days vs 34 days for the "pastelillos"). Certain "empanadilla" flavors contained a higher microbial load than others. However, the greatest difference in microbial counts was observed among the different processors. Some processors elaborated products with a better microbiological quality than others, thus indicating the need to sanitize the manufacturing conditions of some processors.
\end{abstract}

\section{INTRODUCTION}

"Pastelillos" and "empanadillas" are very common foods in Puerto Rico. They consist of a wheat flour dough and a filling that can be a variety of flavors. The filling is placed in the center of a circular piece of flattened dough. One end of the dough is folded over the filling so as to contact the other end. This contact border area is lightly pressed so as to seal the filling inside. The consumer fries the product. The "empanadilla" is generally bigger and has much more filling than the "pastelillo".

The rapid development of the refrigerated and frozen food industry in Puerto Rico and the increasing consumer acceptability of this type of convenience item has made it desirable to conduct a microbiological study to evaluate the condition of these products as they leave the processing plant.

Since this type of food product does not undergo a sterilization process, there exists a potential of foodborne illness resulting from their consumption. This fact, together with the increasing popularity of these foods, poses the need to produce a sound, microbiologically safe finished product.

Knowing the microbiological composition of locally produced and sold frozen and refrigerated foods could enable corrective steps to be taken if abnormalities are found. Such steps would be directed to insure public health and/or to produce a product of superior microbiological quality

${ }^{1}$ Manuscript submitted to Editorial Board February 24, 1984.

${ }^{2}$ Assistant Food Microbiologist, Food Technology Laboratory, Agricultural Experiment Station, Mayagüez Campus, University of Puerto Rico, Rio Piedras, P.R. 
that has a longer shelf life. This would reduce both foodborne illness hazards and economic losses due to premature spoilage.

Up to this date, no information has been published in Puerto Rico regarding the microbiological quality of refrigerated and frozen foods produced and sold locally. This lack of information prompted the development of the present research study, which includes the microbiological quality of selected refrigerated and frozen foods produced by various processors and their expected shelf life under proper storage conditions.

\section{MATERIALS AND METHODS}

In order to determine product shelf life and initial microbial content as these foods leave the processor, samples were purchased directly from the processing plant. Samples included cheese, meat and vegetable protein "pastelillo," and cheese, meat, vegetable protein, pizza, chicken and sausage "empanadillas" from seven different processors.

Upon arrival at the laboratory, samples of each item were analyzed for Aerobic Plate Count (APC), yeast and molds, coliform and fecal coliforms, coagulate positive staphylococci and Salmonella spp. The methods used for the detection and enumeration of these groups of microorganisms were those stipulated in the Bacteriological Analytical Manual for Foods (11) and Standard Methods for the Examination of Dairy Products (1). The rest of the "pastelillos" purchased and some of the "empanadillas" were stored under refrigeration $\left(7^{\circ} \mathrm{C}\right)$ while some other "empanadillas" were freezer stored $\left(-23^{\circ} \mathrm{C}\right)$. Samples of the refrigerated products were withdrawn periodically and microbiologically analyzed as before. This was continued until visible signs of spoilage, as indicated by the appearance of mold growth, were observed. For the frozen "empanadillas", samples were assayed for up to 3.5 months of frozen storage.

\section{RESULTS AND DISCUSSION}

The results indicate that there is great variation in the microbiological quality of the products examined. This finding coincides with reports of other investigators for a variety of frozen and refrigerated items $(3,5,6$, 8).

Table 1 shows the initial microbial load of the products examined as they left the processing plant. Taken as a group, the "pastelillos" generally exhibited lower microbial counts than the "empanadillas". The initial counts, considering all processors, ranged from $1.0 \times 10^{4}$ to $4.0 \times 10^{6}$ bacteria per gram of sample; $9.0 \times 10^{1}$ to $7.2 \times 10^{3}$ yeasts per gram and $<10$ to $4.0 \times 10^{2}$ molds per gram for the "pastelillos". For the "empanadillas" the total counts ranged from $2.0 \times 10^{3}$ to $3.2 \times 10^{7}$ bacteria per gram of sample; $1.6 \times 10^{2}$ to $5.2 \times 10^{4}$ yeasts per gram; and $<10$ to $1.8 \times$ $10^{3}$ molds per gram. 
In the "pastelillos", the greatest difference in microbial numbers was found among brands (processors) than among flavors (cheese, meat, and vegetable protein), whereas in the "empanadillas" differences were observed both among processors and among flavors (cheese, meat, vegetable protein, pizza, chicken and sausage) within the same processor. The pizza flavor was the one that generally exhibited the highest microbial counts.

Regarding the initial contents of indicator bacteria, confirmed coliforms were found in the broad majority of the "pastelillos" and "empanadillas" tested. In the vast majority of cases of confirmed presence of coliforms, all or part of this bacterial population was of fecal origin.

The amount of confirmed coliforms ranged from $<10$ to $4.3 \times 10^{2}$ per gram of sample in the "pastelillos" and from $<10$ to $5.2 \times 10^{4}$ per gram in the "empanadillas." The fecal coliforms ranged from $<10$ to $2.5 \times 10^{2}$ per gram in the "pastelillos" and from $<10$ to $5.2 \times 10^{4}$ in the "empanadillas." "The coliform and fecal coliform counts were considerably higher in the "empanadillas" than in the "pastelillos," and among the "empanadillas" the meat and pizza were the ones most generally contaminated with these microorganisms.

The presence of pathogenic microorganisms, namely coagulase positive staphylococci and Salmonella spp. was not detected in any of the samples tested. This finding coincides with previous reports of a variety of frozen and refrigerated items in which total absence of these pathogens or very low numbers of Staphylococcus aureus were encountered $(2,3,4,5,7,9,10)$.

Table 2 shows the shelf life and the microbial content of the refrigerated products at the time of visible spoilage. These results indicated that the refrigerated "empanadillas" had shorter shelf life than the refrigerated "pastelillos". Among all the samples, the average shelf life of the "pastelillos" was 34 days, whereas that of "empanadillas" was 28 days.

At the time of visible spoilage, the "pastelillos" averaged bacterial count of less than one logarithmic cycle more than initially (in some cases the counts were less than initially), yeast counts of slightly over one logarithmic cycle more than initially and no general change in the mold counts. The "empanadillas" averaged bacterial and yeast counts of less than one logarithmic cycle more than initially (in some cases less than initially) and mold counts of less than one logarithmic cycle less than initially. This information indicates that the microbial content of these products does not increase noticeably upon storage but in fact decreases in some instances. Product spoilage occurs as a consequence of mold growth once enough time has elapsed. However, it is worth noting that no temperature fluctuations occurred since products were stored in the laboratory at uniform temperatures; however, in practice, temperature variations may occur during transportation, handling and retail display that may result in shorter product shelf life. 
TABLE 1.-Initial microbial counts per gram of sample in "pastelillos" and "empanadillas," obtained directly from various processors

\begin{tabular}{|c|c|c|c|c|c|c|c|}
\hline Fast Food & APC & Yeast & Molds & Coliforms & Fecal Coliforms & $\begin{array}{l}\text { Coagulase positive } \\
\text { staphylococci }\end{array}$ & Salmonella spp. \\
\hline \multicolumn{8}{|l|}{ Processor 1} \\
\hline Cheese pastelillo & $1.9 \times 10^{4}$ & $5.0 \times 10^{2}$ & $<10$ & $<10$ & $<10$ & $<10$ & Neg. \\
\hline $\begin{array}{l}\text { Vegetable protein pas- } \\
\text { telillo }\end{array}$ & $1.2 \times 10^{4}$ & $8.5 \times 10^{2}$ & $<10$ & $1.0 \times 10^{2}$ & $5.0 \times 10^{1}$ & $<10$ & Neg. \\
\hline \multicolumn{8}{|l|}{ Processor 2} \\
\hline Cheese pastelillo & $3.9 \times 10^{5}$ & $4.3 \times 10^{3}$ & $4.0 \times 10^{2}$ & $4.3 \times 10^{2}$ & $1.4 \times 10^{2}$ & $<10$ & Neg. \\
\hline Meat pastelillo & $5.3 \times 10^{5}$ & $3.5 \times 10^{3}$ & $1.5 \times 10^{2}$ & $8.2 \times 10^{1}$ & $4.1 \times 10^{1}$ & $<10$ & Neg. \\
\hline Cheese empanadilla & $1.9 \times 10^{7}$ & $1.2 \times 10^{3}$ & $1.0 \times 10^{2}$ & $9.0 \times 10^{1}$ & $6.8 \times 10^{1}$ & $<10$ & Neg. \\
\hline Meat empanadilla & $3.2 \times 10^{7}$ & $1.2 \times 10^{4}$ & $1.5 \times 10^{2}$ & $2.6 \times 10^{4}$ & $8.6 \times 10^{3}$ & $<10$ & Neg. \\
\hline Pizza empanadilla & $8.0 \times 10^{5}$ & $1.5 \times 10^{3}$ & $1.0 \times 10^{2}$ & $2.0 \times 10^{2}$ & $1.1 \times 10^{2}$ & $<10$ & Neg. \\
\hline \multicolumn{8}{|l|}{ Processor 3} \\
\hline Cheese pastelillo & $4.0 \times 10^{6}$ & $7.2 \times 10^{3}$ & $2.0 \times 10^{2}$ & $1.5 \times 10^{2}$ & $5.0 \times 10^{1}$ & $<10$ & Neg. \\
\hline Meat pastelillo & $1.6 \times 10^{5}$ & $6.8 \times 10^{3}$ & $<10^{2}$ & $5.0 \times 10^{1}$ & $5.0 \times 10^{1}$ & $<10$ & Neg. \\
\hline Meat empanadilla & $9.1 \times 10^{6}$ & $6.3 \times 10^{3}$ & $5.0 \times 10^{1}$ & $6.0 \times 10^{2}$ & $2.4 \times 10^{2}$ & $<10$ & Neg. \\
\hline Pizza empanadilla & $1.9 \times 10^{7}$ & $5.2 \times 10^{4}$ & $<10^{2}$ & $5.2 \times 10^{4}$ & $5.2 \times 10^{4}$ & $<10$ & Neg. \\
\hline $\begin{array}{l}\text { Vegetable protein em- } \\
\text { panadilla }\end{array}$ & $1.2 \times 10^{6}$ & $6.4 \times 10^{3}$ & $<10^{2}$ & $1.0 \times 10^{4}$ & $1.0 \times 10^{4}$ & $<10$ & Neg. \\
\hline \multicolumn{8}{|l|}{ Processor 4} \\
\hline Cheese pastelillo & $2.7 \times 10^{4}$ & $5.0 \times 10^{2}$ & $<10^{2}$ & $2.5 \times 10^{2}$ & $2.5 \times 10^{2}$ & $<10$ & Neg. \\
\hline Cheese empanadilla & $1.9 \times 10^{4}$ & $8.0 \times 10^{2}$ & $2.0 \times 10^{2}$ & $<10^{2}$ & $<10^{2}$ & $<10$ & Neg. \\
\hline Meat empanadilla & $1.7 \times 10^{4}$ & $1.5 \times 10^{3}$ & $<10^{2}$ & $1.5 \times 10^{2}$ & $1.5 \times 10^{2}$ & $<10$ & Neg. \\
\hline Pizza empanadilla & $4.2 \times 10^{6}$ & $4.0 \times 10^{4}$ & $1.8 \times 10^{3}$ & $4.0 \times 10^{2}$ & $2.4 \times 10^{2}$ & $<10$ & Neg. \\
\hline \multicolumn{8}{|l|}{ Processor 5} \\
\hline Cheese pastelillo & $1.0 \times 10^{4}$ & $9.5 \times 10^{1}$ & $1.0 \times 10^{1}$ & $3.0 \times 10^{1}$ & $1.5 \times 10^{1}$ & $<10$ & Neg. \\
\hline Meat pastelillo & $6.7 \times 10^{5}$ & $9.0 \times 10^{1}$ & $3.5 \times 10^{1}$ & $1.6 \times 10^{1}$ & $1.6 \times 10^{1}$ & $<10$ & Neg. \\
\hline Cheese empanadilla & $4.0 \times 10^{4}$ & $2.7 \times 10^{3}$ & $2.0 \times 10^{1}$ & $2.4 \times 10^{1}$ & $<10$ & $<10$ & Neg. \\
\hline Meat empanadilla & $4.0 \times 10^{3}$ & $3.9 \times 10^{2}$ & $3.0 \times 10^{1}$ & $2.1 \times 10^{2}$ & $1.1 \times 10^{2}$ & $<10$ & Neg. \\
\hline Pizza empanadilla & $3.3 \times 10^{5}$ & $1.6 \times 10^{2}$ & $1.5 \times 10^{1}$ & $<10$ & $<10$ & $<10$ & Neg. \\
\hline
\end{tabular}




\section{Processor 6}

Cheese pastelillo

Vegetable protein pastelillo

Cheese empanadilla

Vegetable protein empanadilla

Pizza empanadilla

Processor 7

Cheese pastelillo

Vegetable protein pastelillo

Cheese empanadilla

Vegetable protein empanadilla

Chicken empanadilla

Sausage empanadilla

$\begin{array}{lcccccc}5.2 \times 10^{5} & 3.0 \times 10^{2} & 3.0 \times 10^{1} & 2.2 \times 10^{2} & <10 & <10 & \text { Neg. } \\ 5.2 \times 10^{5} & 3.3 \times 10^{2} & <10 & 1.0 \times 10^{1} & <10 & <10 & \text { Neg. } \\ & & & & & & \\ 7.0 \times 10^{3} & 3.3 \times 10^{2} & 1.1 \times 10^{1} & 3.9 \times 10^{1} & <10 & <10 & \text { Neg. } \\ 2.9 \times 10^{4} & 1.7 \times 10^{4} & 3.0 \times 10^{1} & 5.3 \times 10^{2} & 3.5 \times 10^{2} & & \text { Neg. } \\ & & & & <10 & \text { Neg. } \\ 2.0 \times 10^{3} & 3.1 \times 10^{2} & 7.0 \times 10^{1} & 1.2 \times 10^{1} & <10 & <10 & \text { Neg. } \\ 2.5 \times 10^{4} & 4.5 \times 10^{2} & 4.5 \times 10^{1} & <10 & <10 & <10 & \text { Neg. } \\ 3.2 \times 10^{4} & 4.1 \times 10^{2} & 5.5 \times 10^{1} & <10 & <10 & <10 & \text { Neg. } \\ 4.0 \times 10^{4} & 1.7 \times 10^{2} & 4.0 \times 10^{1} & <10 & <10 & <10 & \text { Neg. } \\ 2.4 \times 10^{4} & 5.3 \times 10^{2} & 6.0 \times 10^{1} & 1.6 \times 10^{1} & 1.6 \times 10^{1} & & \text { Neg. } \\ 5.1 \times 10^{4} & 5.7 \times 10^{2} & 1.5 \times 10^{1} & 7.9 \times 10^{2} & 1.6 \times 10^{2} & <10 & \text { Neg. }\end{array}$


TABLE 2.-Microbial counts per gram of sample in "pastelillos" and "empanadillas" at the time of visible spoilage

\begin{tabular}{|c|c|c|c|c|c|c|c|}
\hline Fast Food & $\mathrm{APC}$ & Yeast & Mold & Coliforms & Fecal coliforms & Coagulase positive & $\begin{array}{l}\text { Days elapsed until } \\
\text { visible spoilage } \\
\text { appeared. }\end{array}$ \\
\hline \multicolumn{8}{|l|}{ Processor 1} \\
\hline Cheese pastelillo & $1.1 \times 10^{5}$ & $6.9 \times 10^{4}$ & $<10$ & $<10$ & $<10$ & $<10$ & $48^{2}$ \\
\hline $\begin{array}{l}\text { Vegetable protein pas- } \\
\text { telillo }\end{array}$ & $1.0 \times 10^{7}$ & $>6.5 \times 10^{6}$ & $>3.0 \times 10^{5}$ & $1.5 \times 10^{1}$ & $1.5 \times 10^{1}$ & $<10$ & 35 \\
\hline \multicolumn{8}{|l|}{ Processor 2} \\
\hline Cheese pastelillo & $1.9 \times 10^{5}$ & $1.8 \times 10^{3}$ & $3.5 \times 10^{3}$ & $2.4 \times 10^{2}$ & $2.4 \times 10^{2}$ & $<10$ & 38 \\
\hline Meat pastelillo & $8.7 \times 10^{5}$ & $1.1 \times 10^{4}$ & $<10$ & $<10$ & $<10$ & $<10$ & 38 \\
\hline Cheese empanadilla & $4.3 \times 10^{7}$ & $4.0 \times 10^{2}$ & $5.0 \times 10^{1}$ & $4.4 \times 10^{1}$ & $1.1 \times 10^{1}$ & $<10$ & 22 \\
\hline Meat empanadilla & $2.8 \times 10^{8}$ & $1.1 \times 10^{5}$ & $<10^{3}$ & $3.2 \times 10^{5}$ & $1.3 \times 10^{5}$ & $<10$ & 15 \\
\hline Pizza empanadilla & $2.0 \times 10^{6}$ & $2.7 \times 10^{4}$ & $<10^{2}$ & $7.8 \times 10^{3}$ & $3.9 \times 10^{3}$ & $<10$ & 22 \\
\hline \multicolumn{8}{|l|}{ Processor 3} \\
\hline Cheese pastelillo & $2.5 \times 10^{6}$ & $3.7 \times 10^{3}$ & $<10^{2}$ & $<10^{2}$ & $<10^{2}$ & $<10$ & 20 \\
\hline Meat pastelillo & $1.7 \times 10^{6}$ & $6.3 \times 10^{4}$ & $<10^{2}$ & $<10^{2}$ & $<10^{2}$ & $<10$ & 16 \\
\hline Meat empanadilla ${ }^{3}$ & $3.4 \times 10^{7}$ & $1.7 \times 10^{4}$ & $<10^{2}$ & $2.9 \times 10^{2}$ & $5.8 \times 10^{1}$ & $<10$ & - \\
\hline Pizza empanadilla $^{3}$ & $1.1 \times 10^{6}$ & $7.4 \times 10^{3}$ & $<10^{2}$ & $1.7 \times 10^{5}$ & $6.8 \times 10^{4}$ & $<10$ & 一 \\
\hline $\begin{array}{l}\text { Vegetable protein } \\
\text { empanadilla }^{3}\end{array}$ & $3.0 \times 10^{7}$ & $1.5 \times 10^{3}$ & $<10^{2}$ & $1.2 \times 10^{4}$ & $2.4 \times 10^{3}$ & $<10$ & - \\
\hline \multicolumn{8}{|l|}{ Processor 4} \\
\hline Cheese pastelillo & $2.3 \times 10^{4}$ & $3.0 \times 10^{4}$ & $<10^{2}$ & $<10^{2}$ & $<10^{2}$ & $<10$ & 20 \\
\hline Cheese empanadilla $^{3}$ & $1.3 \times 10^{4}$ & $2.3 \times 10^{2}$ & $<10$ & $1.0 \times 10^{1}$ & $<10$ & $<10$ & - \\
\hline Meat empanadilla ${ }^{3}$ & $2.6 \times 10^{4}$ & $1.3 \times 10^{3}$ & $4.0 \times 10^{1}$ & $4.0 \times 10^{1}$ & $2.4 \times 10^{1}$ & $<10$ & - \\
\hline Pizza empanadilla ${ }^{3}$ & $9.1 \times 10^{5}$ & $1.2 \times 10^{3}$ & $9.0 \times 10^{2}$ & $6.0 \times 10^{1}$ & $3.6 \times 10^{1}$ & $<10$ & - \\
\hline \multicolumn{8}{|l|}{ Processor 5} \\
\hline Cheese pastelillo & $<10^{4}$ & $4.1 \times 10^{2}$ & $1.0 \times 10^{1}$ & $<10$ & $<10$ & $<10$ & 44 \\
\hline Meat pastelillo & $7.0 \times 10^{5}$ & $4.1 \times 10^{5}$ & $<10$ & $<10$ & $<10$ & $<10$ & 36 \\
\hline Cheese empanadilla & $<10^{4}$ & $1.6 \times 10^{5}$ & $<10$ & $<10$ & $<10$ & $<10$ & 36 \\
\hline Meat empanadilla & $1.5 \times 10^{5}$ & $2.2 \times 10^{4}$ & $<10$ & $1.0 \times 10^{1}$ & $<10$ & $<10$ & 29 \\
\hline Pizza empanadilla & $<10^{4}$ & $6.2 \times 10^{2}$ & $1.0 \times 10^{1}$ & $<10$ & $<10$ & $<10$ & 20 \\
\hline
\end{tabular}




\section{Processor 6}

\begin{tabular}{|c|c|c|c|c|c|c|c|}
\hline Cheese pastelillo & $8.5 \times 10^{4}$ & $3.2 \times 10^{3}$ & $3.0 \times 10^{1}$ & $<10$ & $<10$ & $<10$ & 29 \\
\hline $\begin{array}{l}\text { Vegetable protein pas- } \\
\text { telillo }\end{array}$ & $2.0 \times 10^{3}$ & $8.0 \times 10^{1}$ & $<10$ & $<10$ & $<10$ & $<10$ & 36 \\
\hline Cheese empanadilla & $6.7 \times ? 0^{4}$ & $2.0 \times 10^{1}$ & $<10$ & $<10$ & $<10$ & $<10$ & 29 \\
\hline $\begin{array}{l}\text { Vegetable protein em- } \\
\text { panadilla }\end{array}$ & $1.7 \times 10^{5}$ & $5.0 \times 10^{4}$ & $<10$ & $8.8 \times 10^{1}$ & $5.5 \times 10^{1}$ & $<10$ & 20 \\
\hline $\begin{array}{l}\text { Pizza empanadilla } \\
\text { Processor } 7\end{array}$ & $4.0 \times 10^{3}$ & $3.5 \times 10^{3}$ & $<10$ & $<10$ & $<10$ & $<10$ & 36 \\
\hline Cheese pastelillo & $2.0 \times 10^{3}$ & $6.5 \times 10^{2}$ & $<10$ & $<10$ & $<10$ & $<10$ & 44 \\
\hline $\begin{array}{l}\text { Vegetable protein pas- } \\
\text { telillo }\end{array}$ & $1.5 \times 10^{5}$ & $8.0 \times 10^{4}$ & $<10$ & $<10$ & $<10$ & $<10$ & 40 \\
\hline Cheese empanadilla & $7.7 \times 10^{4}$ & $1.5 \times 10^{3}$ & $1.0 \times 10^{1}$ & $<10$ & $<10$ & $<10$ & 36 \\
\hline $\begin{array}{l}\text { Vegetable protein em- } \\
\text { panadilla }\end{array}$ & $4.5 \times 10^{6}$ & $2.4 \times 10^{4}$ & $<10$ & $<10$ & $<10$ & $<10$ & 29 \\
\hline Chicken empanadilla & $8.8 \times 10^{7}$ & $1.6 \times 10^{6}$ & $<10^{2}$ & $<10$ & $<10$ & $<10$ & 29 \\
\hline Sausage empanadilla & $2.3 \times 10^{6}$ & $6.5 \times 10^{3}$ & $1.0 \times 10^{1}$ & $1.0 \times 10^{1}$ & $<10$ & $<10$ & 36 \\
\hline
\end{tabular}

${ }^{1}$ As indicated by external mold growth.

${ }^{2}$ After this period sample still did not exhibit visible mold growth but was discarded because of excessive drying of product.

${ }^{3}$ These samples were frozen. The microbial counts reported correspond to product after 103 days of frozen storage. 
The fact that the "empanadillas" presented higher initial microbial counts than the "pastelillos" could be reasonably attributed to the greater amount of filling of the "empanadillas", since it is likely that contamination is higher in the filling than in the dough used to prepare the product.

The difference in bacterial counts among flavors found in the "empanadillas" denotes the higher susceptibility to contamination of some products over others from the same processor. This is especially noted in pizza-flavored "empanadillas".

The presence of high fecal coliform counts in some of the products tested and the marked differences in product microbiological quality among processors points out the need for microbiological guidelines for these products. The fact that some processors exhibited products of very good microbiological quality (APC in the order of $10^{3}$ per g and less than 10 coliforms, fecal coliforms and coagulase positive staphylococci) proves that refrigerated and frozen "pastelillos" and "empanadillas" can be produced with reasonably low numbers of microorganisms. Other processors elaborated items with a disturbingly poor microbiological quality (APC in the order of $10^{7}$ per $\mathrm{g}$ and coliforms and fecal coliforms in the order of $10^{4}$ per g). These processors ought to be alerted and forced to sanitize their manufacturing practices.

On the basis of results obtained, an APC in the order of $10^{3}$ to $10^{4} / \mathrm{g}$, a coliform count in the order of $10^{1} / \mathrm{g}$, and no detectable presence of fecal coliforms nor coagulase positive staphylococci are recommended as microbiological guidelines for refrigerated and frozen "pastelillos" and "empanadillas."

\section{RESUMEN}

Se llevó a cabo un estudio para determinar la calidad microbiológica de pastelillos y empanadillas, tanto refrigerados como congelados, producidos en el país. Se compraron muestras directamente de siete elaboradores y se les determinó el contenido microbiológico siguiendo métodos estándar corrientes de análisis microbiológico de alimentos. El análisis microbiológico incluyó el conteo total de bacterias, hongos y levaduras, coliformes, coliformes fecales, estafilococos coagulasa positivos y la presencia de especies de Salmonella. También se determinó la duración en almacén para los productos refrigerados almacenándolos a $7^{\circ} \mathrm{C}$ y observando cuándo ocurría un deterioro visible del producto, indicado por el crecimiento de hongos. Los resultados obtenidos indicaron que las empanadillas generalmente arrojaban conteos microbiológicos más elevados que los pastelillos. Almacenadas en frigorífico, las empanadillas se deterioraron más ligero que los pastelillos (28 dias de duración en almacén contra 34). Se observó que algunos tipos de empanadillas eran más susceptibles a 
contaminación que otros. Sin embargo, la mayor diferencia en contaminación microbiológica se observó entre los distintos elaboradores, tanto en las empanadillas como en los pastelillos. Algunos elaboradores confeccionan productos con una mejor calidad microbiológica que otros. Este hecho demuestra la necesidad de mejorar las prácticas de la manufactura de algunos elaboradores.

\section{LITERATURE CITED}

1. American Public Health Association, 1972. Standard Methods for the Examination of Dairy Products, 13th ed, American Public Health Association, Washington, D. C.

2. Dack, G. M., Wheaton, E., Mickelson, M. N. and Schuler, M. N., 1960. Public health significance of microorganisms in frozen pot pies, Quick Frozen Foods 22: 44-45, $160,162$.

3. Dultschaever, C. L., 1978. Bacteriological evaluation of frankfurters in the Canadian retail market, J. Food Prot. 41: 770-74.

4. Foster, J. F., Fowler, J. L. and Dacey, J., 1977. A microbial survey of various fresh and frozen seafood products, J. Food Prot. 40: 300-03.

5. Fruin, J. T., Foster, J. F. and Fowler, J. L., 1978. Survey of the bacterial populations of bologna products, J. Food. Prot. 41: 692-95.

6. Kachikian, R., Fellers, C. R. and Litsky, W., 1959. A bacterial survey of commercial frozen breaded shrimp, J. Milk Food Technol. 22: 310-12.

7. Licciardello, J. J. and Hill, W. S., 1978. Microbiological quality of commercial frozen minced fish blocks, J. Food Prot. 41: 948-52.

8. Litsky, W., Fagerson, I. S. and Fellers, C. R., 1957. A bacteriological survey of commercially frozen beef, poultry and tuna pies, J. Milk Food Technol. 20: 216-19.

9. Surkiewicz, B. F., Campbell, D. F. and Harris, M. E., 1979. Bacteriological survey of frozen Mexican-style foods produced at establishments under federal inspection, J. Food Prot. 42: 46-8.

10. — Harris, M. E. and Johnston, R. W., 1973. Bacteriological survey of frozen meat and gravy produced at establishments under federal inspection, Appl. Microbiol. 26: 574-76.

11. U. S. Department of Health, Education and Welfare, Food and Drug Administration, 1976. Bacteriological Analytical Manual, U. S. Department of Health, Education and Welfare, Washington, D. C. 